\title{
Measurement and clinical implications of choroidal thickness in patients with inflammatory bowel disease
}

\author{
Determinação da espessura da coróide suas implicações clínicas em pacientes com doença \\ inflamatória intestinal
}

Ibrahim Koral Onal ${ }^{1}$, Erdem Yuksel ${ }^{2}$, Kemal Bayrakceken ${ }^{2}$, Muhammed Mustafa Demir ${ }^{1}$, Emine Esra Karaca ${ }^{2}$, Mehmet Ibis $^{1}$, Nasser Alizadeh $^{1}$, Zeynep Gok Sargin ${ }^{1}$, Ahmet Murat Hondur ${ }^{2}$, Mehmet Arhan ${ }^{1}$

\begin{abstract}
Purpose: Ocular inflammation is a frequent extraintestinal manifestation of inflammatory bowel disease (IBD) and may parallel disease activity. In this study, we evaluated the utility of a choroidal thickness measurement in assessing IBD activity. Methods: A total of 62 eyes of 31 patients with IBD [Crohn's disease (CD), $n=10$ and ulcerative colitis (UC), $n=21$ ] and 104 eyes of 52 healthy blood donors were included in this study. Choroidal thickness was measured using enhanced depth imaging optical coherence tomography. The Crohn's disease activity index (CDAI) and the modified Truelove Witts score were used to assess disease activity in CD and UC, respectively.

Results: No significant differences in mean subfoveal, nasal $3000 \mu \mathrm{m}$, or temporal $3000 \mu \mathrm{m}$ choroidal thickness measurements ( $P>0.05$ for all) were observed between IBD patients and healthy controls. Age, smoking, CD site of involvement (ileal and ileocolonic involvement), CDAI, CD activity, and UC endoscopic activity index were all found to be significantly correlated with choroidal thickness by univariate analysis $(P<0.05)$. Smoking $(P<0.05)$ and the $C D$ site of involvement $(P<0.01)$ were the only independent parameters associated with increased choroidal thickness at all measurement locations.
\end{abstract}

Conclusions: Choroidal thickness is not a useful marker of disease activity in patients with IBD but may be an indicator of ileal involvement in patients with CD.

Keywords: Choroid/pathology; Crohn's disease; Inflammatory bowel disease; Optical coherence tomography; Ulcerative colitis; Uveitis

\section{RESUMO}

Objetivos: Inflamação ocular é uma manifestação extra-intestinal comum de doença inflamatória do intestino (IBD) e pode ser paralela a atividade da doença. Neste estudo, investigamos se a espessura da coroideia pode ser útil para avaliar a atividade da IBD. Método: Um total de 62 olhos de 31 pacientes com IBD [10 com doença de Crohn (CD) e 21 colite ulcerosa (UC)] além de 104 olhos de 52 doadores de sangue saudáveis foram incluídos neste estudo. A espessura da coróide foi medida utilizando-se imagens de tomografia de coerência óptica com profundidade aprimorada. O índice de atividade da doença Crohn (CDAl) e o índice de Truelove Witts modificado foram usados para avaliar atividade da doença em CD e UC, respectivamente.

Resultados: Não houve diferença significativa entre os pacientes com IBD e controles saudáveis em termos de medições da espessura da coróide subfoveal média em região 3000 um nasal e 3000 um temporal (p>0,05). Com base na análise univariada; idade, tabagismo, local do envolvimento em CD (ileal ou íleo-cecal), CDAl, atividade CD e indice de atividade endoscópica da UC foram significativamente correlacionados com a espessura da coróide $(p<0,05)$. No entanto, fumar $(p<0,05)$ e o local de envolvimento em $C D(p<0,01)$ foram os únicos parâmetros independentes associados com um aumento na espessura da coroideia em todos os pontos de medida.

Conclusões: A espessura da coroide não é um marcador útil para refletir a atividade da doença em pacientes Com IBD, mas pode ser um indicador de envolvimento ileal em pacientes com CD.

Descritores: Coroide/patologia; Doenças de Crohn;Doenças inflamatórias intestinais/ complicações; Tomografia de coerência óptica; Colite ulcerativa; Uveíte

\section{INTRODUCTION}

Inflammatory bowel disease (IBD) represents a group of inflammatory conditions affecting the colon and small intestine that primarily includes Crohn's disease (CD) and ulcerative colitis (UC). Although intestinal inflammation is the primary process underlying IBD pathology, extraintestinal manifestations (EIMs) are reportedly observed in $5 \%-40 \%$ of patients with IBD and represent the first indication of disease in $10 \%-20 \%$ of cases $^{(1)}$.

Ocular inflammation in IBD was first reported by Crohn in 1925 with a reported prevalence ranging from $4 \%$ to $30 \%(2,3)$. Episcleritis, scleritis, and uveitis are by far the commonest ophthalmic manifestations of IBD, with uveitis the most frequently observed, as patients typically delay treatment for episcleritis that typically has a mild, self limiting course ${ }^{(4)}$. Uveitis has been reported in up to $17 \%$ of patients with IBD and $2 \%$ of uveitis patients reportedly have IBD ${ }^{(4-6)}$. The course of the uveitis may not parallel IBD activity. The prompt diagnosis of uveitis and therapy with topical or systemic steroids is necessary to avoid severe complications.

Spectral domain optical coherence tomography (SD-OCT) is a noninvasive method for studying retinal layer structures in a range of retinal conditions ${ }^{(7)}$. Recently, a new method of SD-OCT, termed enhanced depth imaging (EDI), has been shown to be capable of visualizing the full thickness of the choroid ${ }^{(8)}$. Changes in choroidal thickness have previously been reported in a number of autoimmune and systemic inflammatory disorders ${ }^{(9-13)}$. To the best of our knowledge, studies using EDI-OCT to evaluate choroidal segment involvement in patients with IBD have yet to be reported. 
In this study, we evaluated the efficacy of increased choroidal thickness as a marker of disease activity in patients with IBD.

\section{METHODS}

We performed a cross-sectional study involving EDI-OCT analysis of 62 eyes of 31 IBD patients (CD, $n=10 ; U C, n=21$; mean age, $44.6 \pm$ 13.9years; 11 males; 20 females) and 104 eyes of 52 healthy volunteers (mean age, $44.7 \pm 12.6$ years; 32 males; 20 females). All patients were sequentially recruited into this study. Clinical and laboratory characteristics of IBD patients are presented in table 1 and table 2. Crohn's disease activity was assessed using the Crohn's disease activity index (CDAI). UC disease activity was assessed using the Truelove-Witts score and Lichtiger index ${ }^{(14-16)}$. The Rachmilewitz endoscopic index was used to evaluate endoscopic activity in UC patients ${ }^{(17)}$. Exclusion criteria included spherical equivalent values greater than \pm 4.0 diopters, coexisting ocular disease such as glaucoma or ocular hypertension, and any previous history of ophthalmic surgery, ocular trauma, retinopathy, optic neuropathy or other neurological and systemic vascular disease. The present study was approved by the Gazi University Ethics Committee (26/01/2015 № 53). Informed consent was obtained from all participants prior to examinations.

Table 1. Clinical characteristics of inflammatory bowel disease (IBD) patients

\begin{tabular}{lc}
\hline & IBD $\mathbf{n}=\mathbf{3 1}$ \\
\hline Age, years (mean \pm SD) & $44.6 \pm 13.9$ \\
Sex, male/female & $11 / 20$ \\
Ulcerative colitis, n (\%) & $20(65)$ \\
Crohn's disease, n (\%) & $11(35)$ \\
Disease duration, years, median (min-max) & $4(0.5-29)$ \\
Smoking, n (\%) & $15(48.0)$ \\
Appendectomy, n (\%) & $3(9.7)$ \\
IBD-related surgery, n (\%) & $1(3.2)$ \\
Family history of IBD n (\%) & $3(9.7)$ \\
Medical therapy $n$ (\%) & \\
5-ASA & $29(93.5)$ \\
Aza & $10(32.2)$ \\
Steroids & $10(32.2)$ \\
Anti-TNFa & $2(3.3)$ \\
Medical istory of steroid therapy, $n(\%)$ & $20(65.0)$ \\
\hline
\end{tabular}

$\mathrm{ASA}=$ aminosalycilic acid; $\mathrm{Aza}=$ azathiopurine; $\mathrm{TNF} a=$ transforming growth factor $\mathrm{a}$.

Table 2. Laboratory characteristics of inflammatory bowel disease (IBD) patients

\begin{tabular}{lc}
\hline & IBD $\mathbf{n}=\mathbf{3 1}$ \\
\hline Hemoglobin $(\mathrm{g} / \mathrm{dl})$ & $12.7 \pm 1.9$ \\
Hematocrit & $39.0 \pm 5.6$ \\
Platelet count $\left(/ \mathrm{mm}^{3}\right)$ & $299969 \pm 98175.9$ \\
Serum C-reactive protein level $(\mathrm{mg} / \mathrm{L})$ & $9.8 \pm 9.4$ \\
Eryhtrocyte sedimentation rate $(\mathrm{mm} / \mathrm{hr})$ & $17.9 \pm 13.1$ \\
\hline
\end{tabular}

Numerical values represent mean \pm SD. Normal ranges $=\mathrm{Hb}$ (male $=13.5-17.5 ;$ female $=12-16)$, hematocrit $($ male $=41-53$; female $=36-48)$, platelet counts $\left(150000 / \mathrm{mm}^{3}-40000 / \mathrm{mm}^{3}\right)$, serum C-reactive protein level $(0 \mathrm{mg} / \mathrm{L}-6 \mathrm{mg} / \mathrm{L})$, and erythrocyte sedimentation rate (0 mm/hr-20 mm/hr).
Spherical equivalent refractive error, best corrected visual acuity (BCVA), ocular pressure, slit-lamp biomicroscopy, fundus examination, and ocular inflammation scores based on summed scores of the presence of cells and flares in the anterior chamber and vitreous were evaluated in all patients ${ }^{(18)}$. All participants in the control group had a BCVA equal to 1.0 and no clinical evidence of retinal disease or IBD. The EDI mode of an SD-OCT (Spectralis HRA+OCT; Heidelberg Engineering Inc, Heidelberg, Germany) was used to evaluate choroidal thickness with all measurements obtained by the same operator during morning hours. Twenty-five sections composed of 40 averaged scans were obtained within a $10^{\circ} \times 20^{\circ}$ rectangle centered on the fovea. Two scans, a vertical and a horizontal scan through the centre of the fovea, were selected and choroidal thickness was measured from the outer edge of the retinal pigment epithelium to the inner edge of the suprachoroidal space below the fovea. Foveal scans on the same eye at different time points were conducted under identical scanning conditions automatically retrieved from the follow-up mode of the EDI-OCT system. Measurements were made of the subfoveal choroid and at $3000 \mathrm{~mm}$ nasal and $3000 \mathrm{~mm}$ temporal to the center of the fovea (Figure 1). Choroidal thickness was measured from OCT data from horizontal sections under the center of the fovea by two blinded, independent observers and averaged for analysis.

\section{Statistical analyses}

All statistical analyses were performed using SPSS version 15.0 for Windows (Chicago, IL). Normality was assessed using the Kolmogorov-Smirnov test. Accordingly, data were expressed as median (min-max) or mean \pm SD. Demographic and clinical characteristics were compared among study groups using analysis of variance for continuous variables and chi-squared analysis for dichotomous variables. Correlation analysis for continuous variables was performed using the Pearson correlation coefficient when indicated. Linear regression analyses were used to compare choroidal thickness among the three groups with adjument for age, gender, and BCVA as these variables have previously been associated with a change in choroidal thickness ${ }^{(19-21)}$. Parameters significantly associated with choroidal thickness based on univariate analysis were incorporated into the regression model. A two-sided P-value of 0.05 or less was considered statistically significant.

\section{RESULTS}

Clinical and laboratory indices of study participants are summarized in table 1 and table 2. Subfoveal (IBD group, $329.4 \pm 111.1 \mu \mathrm{m}$ vs control group, $345.1 \pm 85 \mu \mathrm{m}$ ), nasal (IBD group, $297.9 \pm 104.8 \mu \mathrm{m}$ vs control group, $307.1 \pm 82.4 \mu \mathrm{m})$, and temporal (IBD group, $308.7 \pm$ $116.5 \mu \mathrm{m}$ vs control group, $329.9 \pm 85.2 \mu \mathrm{m}$ ) choroidal thickness measurements were not found to significantly differ between patients with IBD and control subjects ( $P>0.05)$. In CD patients, choroidal thickness was greater in patients with isolated ileal involvement compared to those with ileocolonic involvement (Table 3, P<0.01), and in patients with ileocolonic involvement compared to those with isolated colonic involvement (Table 3, P<0.05). The only patient with moderately active CD had a significantly greater choroidal thickness compared to patients with mild CD activity or remission (Table 3, $P<0.05)$. Choroidal thickness was similar among UC patients grouped according to disease activity or the site of involvement (Table 3, $P>0.05)$.

Correlations between choroidal thickness and clinical or laboratory findings were evaluated using Pearson's correlation coefficient. Age, smoking, CD site of involvement (ileal or ileocolonic involvement), CDAI, CD activity, and UC EAI were found to be significantly correlated with choroidal thickness by univariate analysis (Table 4). No correlation was found between choroidal thickness and any other parameter, including erythrocyte sedimentation rate, C-reactive protein level, and platelet number. 
Multiple regression analysis revealed that smoking and CD site of involvement (ileal or ileocolonic involvement) were independently associated with increased choroidal thickness at all measurement locations (Table 5).

\section{DISCUSSION}

This study demonstrated that choroidal thickness was similar between patients with IBD and healthy control subjects. No significant correlations were observed between choroidal thickness and clinical, laboratory, and endoscopic parameters of IBD activity. Therefore, choroidal thickness does not appear to have utility as an activity marker in IBD. However, choroidal thickness was found to be greater in CD patients with ileal involvement, a finding that merits further research and discussion.

OCT has been used to evaluate choroid thickness in patients with a number of systemic autoimmune and inflammatory disorders ${ }^{(9-13)}$. Patients with active Vogt-Koyanagi-Harada disease have been shown to have markedly increased choroidal thickness, possibly related to inflammatory infiltration and increased exudation ${ }^{(9)}$. In these patients, increased choroidal thickness and exudative retinal detachment rapidly resolved following treatment with corticosteroids ${ }^{(9)}$. Subfoveal choroidal thickness during the acute phase of uveitis in patients with Behçet's disease has been shown to be greater than during the remission phase, and decreases in choroidal thickness accompanied the amelioration of ocular inflammation in response to infliximab(11). Choroidal thickness was found to be significantly correlated with total, anterior, and posterior inflammatory scores in this study ${ }^{(11)}$. Gungor et al. reported patients with posterior ocular sarcoidosis in the absence of active ocular inflammation had decreased choroidal thickness compared to normal subjects during the quiescent phase of the disease ${ }^{(12)}$, however, the authors were unable to provide a satisfactory explanation for this finding. Kola et al. reported increased choroidal thickness in patients with ankylosing spondylitis compared to healthy controls ${ }^{(13)}$. The authors proposed that chronic systemic inflammation may play an important role in the thickening of the choroid layer in patients with ankylosing spondylitis ${ }^{(13)}$. However, found to no significant correlation between chorodial thickness and systemic inflammatory markers ${ }^{(13)}$.

The eyes are one of the most common sites of extraintestinal involvement in patients with IBD. The majority of patients are diagnosed with IBD prior to the development of ophthalmic complications, however ocular disorders may be the initial manifestion of IBD $^{(22)}$. Uveitis is the most worrisome complication as, if left untreated, it may lead to permanent vision loss. Nongranulomatous, low-grade, recurrent, acute anterior uveitisis is the most common type of IBD-associated uveitis, however posterior uveitis may also occur with chorioretinitis described in 10\% of patients in one case series ${ }^{(23)}$. Steroid-responsive choroidal infiltrates and scattered patches of choroidal inflammation with overlying serous retinal detachment have all been previously described in IBD patients ${ }^{(24)}$. Opthalmic complications are associated with active IBD in the majority of cases, but not invariably ${ }^{(25)}$.

To the best of our knowledge, our study is the first to measure choroidal thickness in patients with IBD. No ocular complications were expected in this cohort as none of the patients had previously described any relevant ocular symptoms prior to examination. Although we found significant correlations between choroidal thickness and IBD disease activity (CDAI and UC EAI), these associations were lost after adjustment for covariates. However, ileal involvement remained independently associated with increased choroidal thickness after multivariate analysis.

Ocular complications of IBD are often accompanied by other extraintestinal manifestations, particularly arthritis and erythema nodosum. Similarities between the microvasculature of the synovium and the uvea may play a role in this association as both have a capacity for enhanced antigen presentation, leukocyte migration, and cytokine activity ${ }^{(26)}$. Recent evidence indicates inflammatory responses against a specific colon epithelial protein may lead to cross-reaction against antigens present in the eyes, joints, skin, and biliary tract during the development of extraintestinal manifestations ${ }^{(26)}$. The identification
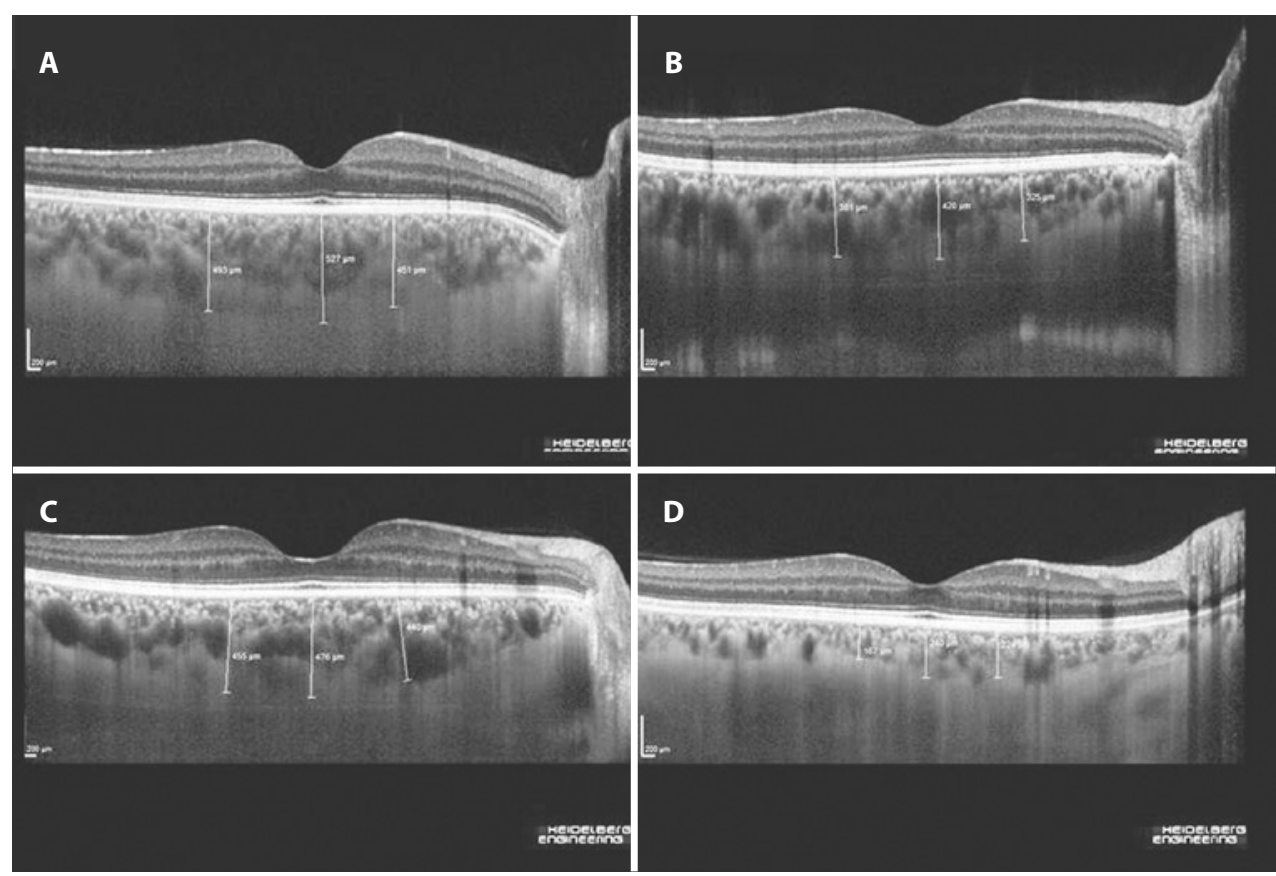

Figure 1. Enhanced depth imaging-spectral domain optical coherence tomography images obtained from patients with inflammatory bowel disease. A) Moderately active ulcerative colitis with an endoscopic activity index of 11. B) Mildly active ulcerative colitis with an endoscopic activity index of 2. C) Moderately active Crohn's disease with a Crohn's disease activity index of 255 . D) Crohn's disease on remission with a Crohn's disease activity index of 14. 
Table 3. Mean choroidal thickness measurements in inflammatory bowel disease patients according to disease severity and site of involvement

\begin{tabular}{|c|c|c|c|c|}
\hline Parameter (number of patients) & N3000 & $\mathbf{F}$ & T3000 & P-value \\
\hline$C D(10)$ & & & & $<0.05$ moderate vs mild-remission \\
\hline Remission (8) & $257.0 \pm 75.9$ & $275.0 \pm 86.4$ & $242.3 \pm 69.2$ & \\
\hline Mild (1) & $250.0 \pm 7.0$ & $265.0 \pm 14.1$ & $240.0 \pm 63.6$ & \\
\hline Moderate(1) & $445.0 \pm \quad 7.0$ & $477.5 \pm \quad 3.5$ & $472.5 \pm 74.7$ & \\
\hline UC (21) & & & & $>0.05$ \\
\hline Mild (13) & $301.2 \pm 106.6$ & $334.3 \pm 109.4$ & $314.1 \pm 117.1$ & \\
\hline Crohn's disease (10) & & & & $<0.05$ among the three groups \\
\hline Ileum (6) & $324.7 \pm 75.6$ & $350.7 \pm 82.5$ & $316.0 \pm 82.9$ & \\
\hline Ileum-colon (3) & $221.2 \pm 26.8$ & $232.0 \pm 29.9$ & $204.8 \pm 49.7$ & \\
\hline Colon (1) & $140.0 \pm 28.3$ & $142.5 \pm 10.6$ & $140.0 \pm 14.1$ & \\
\hline Ulcerative colitis (21) & & & & $>0.05$ \\
\hline Proctitis (4) & $224.1 \pm 61.4$ & $280.6 \pm 88.1$ & $264.9 \pm 91.5$ & \\
\hline Left-sided colitis (9) & $340.3 \pm 121.9$ & $367.3 \pm 133.9$ & $345.7 \pm 133.9$ & \\
\hline Extensive colitis (6) & $339.7 \pm 91.9$ & $385.3 \pm 80.4$ & $366.7 \pm 110.8$ & \\
\hline Pancolitis (2) & $242.7 \pm 95.9$ & $264.7 \pm 64.6$ & $274.0 \pm 106.4$ & \\
\hline
\end{tabular}

$\mathrm{F}=$ fovea; $\mathrm{N}=$ nasal; $\mathrm{T}=$ temporal. Numerical values represent mean $\pm \mathrm{SD}$. $\mathrm{CD}=$ Crohn's disease; $\mathrm{UC}=$ Ulcerative colitis.

Table 4. Clinical and laboratory parameters significantly associated with choroidal thickness by univariate analysis and associated Pearson's correlation coefficients

\begin{tabular}{|c|c|c|c|c|c|c|}
\hline & \multicolumn{2}{|c|}{ N3000 } & \multicolumn{2}{|c|}{$\mathbf{F}$} & \multicolumn{2}{|c|}{ T3000 } \\
\hline & Coefficient & P-value & Coefficient & P-value & Coefficient & P-value \\
\hline Age & -0.339 & $<0.01$ & -0.376 & $<0.01$ & -0.402 & $<0.01$ \\
\hline$C D^{*}$ & 0.742 & $<0.01$ & 0.756 & $<0.01$ & 0.692 & $<0.01$ \\
\hline CDAl & 0.538 & $<0.05$ & 0.581 & $<0.01$ & 0.643 & $<0.01$ \\
\hline CD activity & 0.566 & $<0.01$ & 0.544 & $<0.05$ & 0.656 & $<0.01$ \\
\hline
\end{tabular}

$\mathrm{F}=$ fovea; $\mathrm{N}=$ nasal; $\mathrm{T}=$ temporal. Numerical values represent mean $\pm \mathrm{SD}$. $\mathrm{CD}=$ Crohn's disease; $\mathrm{UC}=$ Ulcerative colitis; $\mathrm{CDAl}=$ Crohn's disease activity index; EAl= endoscopic activity index. Detailed information regarding individual parameters are presented in tables 1,2 , and $3 .{ }^{*}=$ site of disease involvement.

Table 5. Multivariate analysis of the effect of potential confounders on choroidal thickness measurements

\begin{tabular}{|c|c|c|c|c|c|c|c|c|c|}
\hline & \multicolumn{3}{|c|}{ N3000 } & \multicolumn{3}{|c|}{$\mathbf{F}$} & \multicolumn{3}{|c|}{ T3000 } \\
\hline & B & SE & $\mathbf{P}$ & B & SE & $\mathbf{P}$ & B & SE & $\mathbf{P}$ \\
\hline Age & -1.76 & 1.62 & 0.30 & -5.0 & 1.6 & 0.01 & -0.70 & 2.00 & 0.74 \\
\hline CD involvement* & 102.20 & 16.30 & $<0.01$ & 88.8 & 16.0 & $<0.01$ & 93.10 & 20.10 & $<0.01$ \\
\hline CDAl & 0.25 & 0.35 & 0.49 & 0.9 & 0.3 & 0.02 & -0.07 & 0.44 & 0.87 \\
\hline CD activity & 6.40 & 44.70 & 0.89 & -66.2 & 43.9 & 0.16 & 75.70 & 55.70 & 0.20 \\
\hline
\end{tabular}

$\mathrm{CDAl}=$ Crohn's disease activity index; EAl= Rachmilewitz endoscopic activity index. ${ }^{*}=$ site of disease involvement; $\mathrm{B}=$ unstandardized coefficients of the estimated regression model; $\mathrm{SE}=$ standard error of the coefficients; $P=P$-value. 
of a similar antigen expressed by ileal epithelial cells with molecular mimicry may explain the increased choroidal thickness observed in patients with ileal involvement in our series. The microvasculature is thought to play a critical role in mediating inflammation. There is growing evidence of widespread inflammatory vasculitis with activation of the clotting cascade leading to microvascular damage and inflammation in the interstitial wall of blood vessels during the development of IBD ${ }^{(27-28)}$. Angiogenesis has emerged as an additional vascular mechanism contributing to chronic inflammation in IBD ${ }^{(29-30)}$. Vasculitic and pro-thrombotic changes and increased angiogenesis may also affect the ocular microvascular bed and mediate the development of ocular complications.

In conclusion, choroidal thickness was not found to have utility as an activity marker in patients with IBD, however ileal involvement in CD was found to be associated with increased choroidal thickness. Further research on the assocation between ileal involvement and choroidal thickness may contribute to our understanding of the pathogenesis of ocular complications in IBD. This study identified smoking as an independent predictor of increased choroidal thickness and should be considered as a potential confounding factor in future studies.

\section{REFERENCES}

1. Bernstein CN. Extraintestinal manifestations of inflammatory bowel disease. Curr Gastroenterol Rep. 2001:3(6):477-83.

2. Felekis T, Katsanos K, Kitsanou M, Trakos N, Theopistos V, Christodoulou D, et al. Spectrum and frequency of ophthalmologic manifestations in patients with inflammatory bowel disease: a prospective single-center study. Inflamm Bowel Dis. 2009;15(1):29-34.

3. Greenstein AJ, Janowitz HD, Sachar DB. The extra-intestinal complications of Crohn's disease and ulcerative colitis: a study of 700 patients. Medicine. 1976;55(5):401-12.

4. Hopkins DJ, Horan E, Burton IL, Clamp SE, de Dombal FT, Goligher JC. Ocular disorders in a series of 332 patients with Crohn's disease. Br J Ophthalmol. 1974;58(8):732-7.

5. Knox DL, Schachat AP, Mustonen E. Primary, secondary and coincidental ocular complications of Crohn's disease. Ophthalmology. 1984;91(2):163-73.

6. McCannel CA, Holland GN, Helm CJ, Cornell PJ, Winston JV, Rimmer TG. Causes of uveitis in the general practice of ophthalmology. UCLA Community-Based Uveitis Study Group. Am J Ophthalmol. 1996;121(1):35-46.

7. Hassenstein A, Meyer CH. Clinical use and research applications of Heidelberg retinal angiography and spectral-domain optical coherence tomography-a review. Clin Experiment Ophthalmol. 2009;37(1):130-43.

8. Spaide RF, Koizumi H, Pozonni MC. Enhanced depth imaging spectral-domain optical coherence tomography. Am J Ophthalmol. 2008;146(4):496-500.

9. Maruko I, lida T, Sugano Y, Oyamada H, Sekiryu T, Fujiwara T, et al. Subfoveal choroidal thickness after treatment of Vogt-Koyanagi-Harada disease. Retina. 2011;31(3):510-7.

10. Fong $\mathrm{AH}$, Li KK, Wong D. Choroidal evaluation using enhanced depth imaging spectral-domain optical coherence tomography in Vogt-Koyanagi-Harada disease. Retina. 2011;31(3):502-9.
11. Ishikawa S, Taguchi M, Muraoka T, Sakurai Y, Kanda T, Takeuchi M. Changes in subfoveal choroidal thickness associated with uveitis activity in patients with Behçet's disease. Br J Ophthalmol. 2014;98(11):1508-13.

12. Gungor SG, Akkoyun I, Reyhan NH, Yeşilırmak N, Yılmaz G. Choroidal thickness in ocular sarcoidosis during quiescent phase using enhanced depth imaging optical coherence tomography. Ocul Immunol Inflamm. 2014;22(4):287-93.

13. Kola M, Kalkisim A, Karkucak M, Turk A, Capkin E, Can I, et al. Evaluation of choroida thickness in ankylosing spondylitis using optical coherence tomography. Ocul Immunol Inflamm. 2014;22(6):434-8.

14. Best WR, Becktel JM, Singleton JW, Kern F Jr. Development of a Crohn's disease activity index. National Cooperative Crohn's Disease Study. Gastroenterology. 1976;70(3):439-44.

15. Truelove SC, Witts $L J$. Cortisone in ulcerative colitis; final report on a therapeutic trial. Br Med J. 1955;2(4947):1041-8.

16. Lichtiger S, Present DH, Kornbluth A, Gelernt I, Bauer J, Galler G, et al. Cyclosporine in severe ulcerative colitis refractory to steroid therapy. N Engl J Med. 1994;330(26):1841-5.

17. Rachmilewitz D. Coated mesalazine (5-ASA. versus sulphasalazine in the treatment of active ulcerative colitis: a randomized trial. BMJ. 1989;298(6666):82-6.

18. Nussenblatt RB, Palestine AG, Chan CC, Roberge F. Standardization of vitreal inflammatory activity in intermediate and posterior uveitis. Ophthalmology. 1985;92(4):467.

19. Tuncer I, Karahan E, Zengin MO, Atalay E, Polat N. Choroidal thickness in relation to sex, age, refractive error, and axial length in healthy Turkish subjects. Int Ophthalmol. 2014;35(3):403-10

20. Margolis R, Spaide RF. A pilot study of enhanced depth imaging optical coherence tomography of the choroid in normal eyes. Am J Ophthalmol. 2009;147(5):811-5.

21. Ikuno Y, Kawaguchi K, Nouchi T, Yasuno Y. Choroidal thickness in healthy Japanese subjects. Invest Ophthalmol Vis Sci. 2010;51(4):2173-6.

22. Lyons JL, Rosenbaum JT. Uveitis associated with inflammatory bowel disease compared with uveitis associated with spondyloarthropathy. Arch Ophthalmol. 1997;115(1): 61-4.

23. Bañares A, Jover JA, Fernández-Gutiérrez B, Benítez del Castillo JM, García J, Vargas E, et al. Patterns of uveitis as a guide in making rheumatologic and immunologic diagnoses. Arthritis Rheum. 1997:40(2):358-70

24. Ernst BB, Lowder CY, Meisler DM, Gutman FA. Posterior segment manifestations of inflammatory bowel disease. Ophthalmology. 1991;98(8):1272-80.

25. Hopkins DJ, Horan E, Burton IL, Clamp SE, de Dombal FT, Goligher JC. Ocular disorders in a series of 332 patients with Crohn's disease. Br J Ophthalmol. 1974;58(8):732-7.

26. Das KM. Relationship of extraintestinal involvements in inflammatory bowel disease: new insights into autoimmune pathogenesis. Dig Dis Sci. 1999;44(1):1-13.

27. Duker JS, Brown GC, Brooks L. Retinal vasculitis in Crohn's disease. Am J Ophthalmol. 1987;103(5):664-8.

28. Hudson M, Chitolie A, Hutton RA, Smith MS, Pounder RE, Wakefield AJ. Thrombotic vascular risk factors in inflammatory bowel disease. Gut. 1996;38(5):733-7.

29. Chidlow JH Jr, Shukla D, Grisham MB, Kevil CG. Pathogenic angiogenesis in IBD and experimental colitis: new ideas and therapeutic avenues. Am J Physiol Gastrointest Liver Physiol. 2007;293(1):5-18.

30. Danese S, Sans M, de la Motte C, Graziani C, West G, Phillips MH. Angiogenesis as a novel component of inflammatory bowel disease pathogenesis. Gastroenterology 2006;130(7):2060-73. 